\title{
Front Matter: Volume 11054
}

, "Front Matter: Volume 11054," Proc. SPIE 11054, Superconductivity and Particle Accelerators 2018, 1105401 (16 May 2019); doi: 10.1117/12.2537945

EDent: Superconductivity and Particle Accelerators 2018, 2018, Krakow, SPIE. Poland 


\section{PROCEEDINGS OF SPIE}

\section{Superconductivity and Particle Accelerators 2018}

Dariusz Bocian

Ryszard S. Romaniuk

Editors

27-29 November 2018

Kraków, Poland

Organized by

The Henryk Niewodniczański Institute of Nuclear Physics, Polish Academy of Sciences (Poland)

Published by

SPIE

Volume 11054

Proceedings of SPIE 0277-786X, V. 11054

SPIE is an international society advancing an interdisciplinary approach to the science and application of light.

Superconductivity and Particle Accelerators 2018, edited by Dariusz Bocian,

Ryszard S. Romaniuk, Proc. of SPIE Vol. 11054, 1105401 - ( 2019 SPIE

CCC code: $0277-786 X / 19 / \$ 18 \cdot$ doi: $10.1117 / 12.2537945$

Proc. of SPIE Vol. 11054 1105401-1

Downloaded From: https://www.spiedigitallibrary.org/conference-proceedings-of-spie on 26 Apr 2023 Terms of Use: https://www.spiedigitallibrary.org/terms-of-use 
The papers in this volume were part of the technical conference cited on the cover and title page. Papers were selected and subject to review by the editors and conference program committee. Some conference presentations may not be available for publication. Additional papers and presentation recordings may be available online in the SPIE Digital Library at SPIEDigitalLibrary.org.

The papers reflect the work and thoughts of the authors and are published herein as submitted. The publisher is not responsible for the validity of the information or for any outcomes resulting from reliance thereon.

Please use the following format to cite material from these proceedings:

Author(s), "Title of Paper," in Superconductivity and Particle Accelerators 2018, edited by Dariusz Bocian, Ryszard S. Romaniuk, Proceedings of SPIE Vol. 11054 (SPIE, Bellingham, WA, 2019) Seven-digit Article CID Number.

ISSN: 0277-786X

ISSN: 1996-756X (electronic)

ISBN: 9781510627833

ISBN: 9781510627840 (electronic)

Published by

SPIE

P.O. Box 10, Bellingham, Washington 98227-0010 USA

Telephone +1 3606763290 (Pacific Time) · Fax +1 3606471445

SPIE.org

Copyright (C) 2019, Society of Photo-Optical Instrumentation Engineers.

Copying of material in this book for internal or personal use, or for the internal or personal use of specific clients, beyond the fair use provisions granted by the U.S. Copyright Law is authorized by SPIE subject to payment of copying fees. The Transactional Reporting Service base fee for this volume is $\$ 18.00$ per article (or portion thereof), which should be paid directly to the Copyright Clearance Center (CCC), 222 Rosewood Drive, Danvers, MA 01923. Payment may also be made electronically through CCC Online at copyright.com. Other copying for republication, resale, advertising or promotion, or any form of systematic or multiple reproduction of any material in this book is prohibited except with permission in writing from the publisher. The CCC fee code is 0277$786 \mathrm{X} / 19 / \$ 18.00$.

Printed in the United States of America by Curran Associates, Inc., under license from SPIE.

Publication of record for individual papers is online in the SPIE Digital Library.

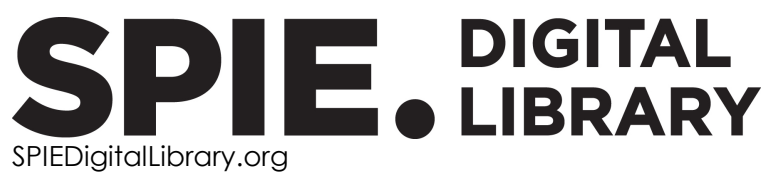

Paper Numbering: Proceedings of SPIE follow an e-First publication model. A unique citation identifier (CID) number is assigned to each article at the time of publication. Utilization of CIDs allows articles to be fully citable as soon as they are published online, and connects the same identifier to all online and print versions of the publication. SPIE uses a seven-digit CID article numbering system structured as follows:

- The first five digits correspond to the SPIE volume number.

- The last two digits indicate publication order within the volume using a Base 36 numbering system employing both numerals and letters. These two-number sets start with $00,01,02,03,04$, 05, 06, 07, 08, 09, 0A, OB ... 0Z, followed by 10-1Z, 20-2Z, etc. The CID Number appears on each page of the manuscript. 


\title{
Contents
}

\author{
$\checkmark \quad$ Authors \\ vii Symposium Committees \\ xi Introduction
}

SYMPOSIUM OVERVIEW

1105402 Superconductivity and particle accelerators 2018: SPAS'2018 conference overview (Invited Paper) [1 1054-1]

1105403 Development of particle accelerator technology in Europe: digest of infrastructural and research projects (Invited Paper) [1 1054-2]

\section{LARGE ACCELERATORS AND RESEARCH INFRASTRUCTURES}

1105404 The day after LHC: electron-positron colliders are marching on (Invited Paper) [1 1054-5]

$1105405 \quad$ Polish free electron laser: short technical description (Invited Paper) [1 1054-35]

1105406 Progress towards continuous wave operation of the SRF Linac at DESY (Invited Paper) [1 1054-7]

1105407 Polish contribution to final beam dynamic calculations for accelerator system analysis in the Early Neutron Source project [11054-11]

1105408 Development of cryogenic test infrastructure at IFJ PAN [1 1054-15]

1105409 Thermal-hydraulic analysis of the upgraded EU-DEMO CS1 coil [1 1054-27]

11054 OA IFJ PAN contribution to the ESS: radio frequency distribution system, power converters installation, and cryomodule tests (Invited Paper) [11054-18]

11054 OB IFJ PAN's contribution to the HL-LHC: construction of the superconducting links [1 1054-25]

11054 OC IFJ PAN's contribution to the HL-LHC: crab cavities and RF [1 1054-28]

11054 OD IFJ PAN's contribution to the HL-LHC: DQW crab cavity preparation and testing at CERN [1 1054-26] 


\section{BASIC RESEARCH ON MATERIALS AND COMPONENTS}

$11054 \mathrm{OE} \quad$ Modelling of the influence of heavy ions irradiation on the current-voltage characteristics of the HTc superconducting tapes subjected to the bending strain process (Invited Paper) [11054-6]

11054 OF Superconducting single-photon detectors as smart sensors [1 1054-34]

11054 OG Numerical study of thin superconducting plates subjected to transverse magnetic fields [11054-9]

$11054 \mathrm{OH} \quad$ Infiltration growth processing of bulk mixed $\mathrm{REBa}_{2} \mathrm{CU}_{3} \mathrm{O}_{7-x}$ superconductors: nano-metal oxides and rare earth elements effects on microstructural properties [11054-10]

11054 Ol Improved superconducting performance of Ag-added nano-diamond doped MgB2 [1 1054-13]

11054 0J Physico-chemical properties of ceramic high-temperature superconductors with an approximate average radius of rare earth ion(-s) obtained by a solid-state synthesis reaction [11054-32]

11054 OK Critical currents and critical temperatures of oxygenated TI-2223 bulk superconductors [11054-31]

$11054 \mathrm{OL} \quad$ Studies of oxygen superconductors $\mathrm{REBa}_{2} \mathrm{CU}_{3} \mathrm{O}_{7-\delta}$ (where RE rare earth) using an EPR method [11054-8]

11054 OM From two types of electrostatic position-dependent semiconductor qubits to quantum universal gates and hybrid semiconductor-superconducting quantum computer [1 1054-14]

$11054 \mathrm{ON}$ The microstructure and dielectric properties of a solid solution (1-x) $\mathrm{K}_{0.5} \mathrm{Bi}_{0.5} \mathrm{TiO}_{3}-\mathrm{x} \mathrm{SrTiO}_{3}$ for $x=0.001$ ceramics $[11054-3]$ 


\section{Authors}

Numbers in the index correspond to the last two digits of the seven-digit citation identifier (CID) article numbering system used in Proceedings of SPIE. The first five digits reflect the volume number. Base 36 numbering is employed for the last two digits and indicates the order of articles within the volume. Numbers start with 00, 01, 02, 03, 04, 05, 06, 07, 08, 09, OA, OB...0Z, followed by 10-1Z, 20-2Z, etc.

Bar, J., OF

Blokhina, Elena, $\mathrm{OM}$

Bocian, Dariusz, 02, 03, 08, OA, OB, OC, OD, OJ

Czaja, P., ON

Czuma, P., 05

Dadiel, J. Longji, Ol

Dembkowska, Aleksandra, 09

Drzymała, Elżbieta, 0J

Duda, M., 08

Dutkiewicz, Erazm M., 0J

Dziubaniuk, M., ON

Eisaki, Hiroshi, $\mathrm{OH}$

Fuks, Hubert, OL

Gaj, W., OA

Giebułtowski, Marek, OK

Giounanlis, Panagiotis, OM

Gondek, Łukasz, OK

Gornicki, E., OA

Grabowski, W., 07

Guziewicz, M., OF

Hajduk, L., OA

Halczynski, P., OA

Heidinger, R., 07

Iwasa, Yuki, OH

Jastrzębski, Cezariusz, OJ

Kaczmarek, Sławomir M., OL

Kasprzak, K., OA

Klimov, A., OF

Kluczewska-Chmielarz, K., ON

Koblischka, M. R., OH

Koblischka-Veneva, A., $\mathrm{OH}$

Konieczny, Piotr, OJ

Kosiński, K., 07

Kostin, D., 06

Kowalik, Marcin, OK

Krawczyk, A., OB, OC, OD

Krawczyk, P., 05

Kruszka, R., OF

Kurek, K., 05

Leipold, Dirk, OM

Lesiak, Tadeusz, 04

Lewandowska, Monika, 09

Lorkiewicz, J., 05

Maciocha, W., 08

Maćkowski, M., 07

Malecki, Piotr, 03

Murakami, $\mathrm{M} ., \mathrm{OH}, \mathrm{Ol}$

Muralidhar, M., $\mathrm{OH}, \mathrm{OI}$

Myalski, K., OA
Nagaveni, K., $\mathrm{OH}$

Nietubyć, R., 05

Niewolski, Janusz, OK

Ogino, Hiraku, OH

Oka, T., $\mathrm{OH}$

Ostrowicz, T., OA

Panas, A., OF

Pavan Kumar Naik, S., $\mathrm{OH}$

Pęczkowski, Paweł, OJ, OL, OM

Poliński, J., 05

Pomorski, Krzysztof, OM

Prochal, B., OB, OC, OD

Romaniuk, Ryszard S., 02, 03

Sarasola, Xabier, 09

Sekutowicz, J., 05, 06

Sienkiewicz, M., OA

Skiba, M., OA

Słysz, W., OF

Sosnowski, J., OE

Staszczak, M., 05, 07

Staszewski, Robert Bogdan, OM

Suchanicz, J., ON

Swarup Raju, P. Missak, $\mathrm{OH}$

Swierblewski, J., 08, 0A

Szamota-Leandersson, K., 05

Szeliga, A., 08

Szewiński, J., 05

Tomków, Łukasz, OG

Wartak, M., OC, OD

Wąs, M., ON

Wegrzecki, M., OF

Woch, Wiesław Marek, OK

Wysocka-Rabin, A., 07

Zachariasz, Piotr, 0J

Zalecki, Ryszard, OK

Zarzycki, Arkadiusz, OJ

Zwoźniak, A., OB, OC, OD 
Proc. of SPIE Vol. 11054 1105401-6 Downloaded From: https://www.spiedigitallibrary.org/conference-proceedings-of-spie on 26 Apr 2023
Terms of Use: https://www.spiedigitallibrary.org/terms-of-use 


\section{Symposium Committees}

Honorary Patronage

Marek Jezabek, Institute of Nuclear Physics (Poland)

Scientific Program Committee

Dariusz Bocian, Chair, Institute of Nuclear Physics (Poland) Krzysztof Brodziński, CERN (Switzerland)

Maciej Chorowski, Wrocław University of Science and Technology (Poland)

Krzysztof Czuba, Warsaw University of Technology (Poland)

Sandor Feher, Fermi National Accelerator Laboratory (United States) Jarosław Fydrych, European Spallation Source (Sweden) Marek Gąsior, CERN (Switzerland)

Artur Kawecki, AGH University of Science and Technology (Poland) Tadeusz Lesiak, Institute of Nuclear Physics (Poland)

Monika Lewandowska, West Pomeranian University of Technology Szczecin (Poland)

Dariusz Makowski, Łódź University of Technology (Poland)

Piotr Malecki, Institute of Nuclear Physics (Poland)

Andrzej Morawski, IWC, Warsaw (Poland)

Andrzej Napieralski, Łódź University of Technology (Poland)

Paweł Pęczkowski, Institute of Nuclear Physics (Poland)

Slawomir Pietrowicz, Wrocław University of Science and Technology (Poland)

Jaroslaw Poliński, Wrocław University of Science and Technology (Poland)

Ryszard S. Romaniuk, Warsaw University of Technology (Poland) Jacek Sekutowicz, DESY Hamburg (Germany)

Andrzej Siemko, CERN (Switzerland)

Błażej Skoczeń, Kraków University of Technology (Poland)

Marek Woch, AGH University of Science and Technology (Poland)

Sławomir Wronka, National Centre for Nuclear Research (Poland)

Andrzej Zaleski, Institute of Low Temperature and Structure Research (Poland)

Local Organizing Committee

Dariusz Bocian, Chair, Institute of Nuclear Physics (Poland)

Michał Duda, Institute of Nuclear Physics (Poland)

Artur Krawczyk, Institute of Nuclear Physics (Poland)

Katarzyna Kwiatkowska, Institute of Nuclear Physics (Poland)

Jaromir Ludwin, Institute of Nuclear Physics (Poland) 
Wojciech Marek, Institute of Nuclear Physics (Poland)

Paweł Pęczkowski, Institute of Nuclear Physics (Poland)

Jacek Świerblewski, The Henryk Niewodniczanski Institute of Nuclear

Physics (Poland)

Olawia Woźnicka, Institute of Nuclear Physics (Poland)

Agnieszka Zwoźniak, Institute of Nuclear Physics (Poland)

\section{Technical Committee}

Dariusz Bocian, Chair, Institute of Nuclear Physics (Poland)

Michał Duda, Institute of Nuclear Physics (Poland)

Pawel Pęczkowski, Institute of Nuclear Physics (Poland)

Ryszard S. Romaniuk, Co-chair, Warsaw University of Technology (Poland)

Artur Krawczyk, Institute of Nuclear Physics (Poland)

Agnieszka Zwoźniak, Institute of Nuclear Physics (Poland)

Session Chairs

Physics in Large Accelerators

Dariusz Bocian, Institute of Nuclear Physics (Poland)

HL-LHC: High Luminosity Large Hadron Collider

Krzysztof Brodziński, CERN (Switzerland)

Superconductors: HTC

Dariusz Bocian, Institute of Nuclear Physics (Poland)

Superconductors: $\mathrm{MgB}_{2}$

Monika Lewandowska, West Pomeranian University of Technology

Szczecin (Poland)

Challenges in Large Scientific Facilities

Dariusz Bocian, Institute of Nuclear Physics (Poland)

European Spallation Source - ESS

Zbigniew Golębiewski, National Centre for Nuclear Research (Poland)

Challenges in Superconductivity and Accelerators

Adrian Szeliga, Institute of Nuclear Physics (Poland)

Superconducting RF - SRF

Agnieszka Zwoźniak, Institute of Nuclear Physics (Poland)

POLFEL: Polish Free Electron Laser

Jacek Sekutowicz, DESY Hamburg (Germany) 
Challenges in Low Temperature Engineering

Dariusz Makowski, Łódź University of Technology (Poland)

Smart Materials

Dariusz Makowski, Łódź University of Technology (Poland)

Research, Technological Infrastructures, and Industry: European and National Coactions

Piotr Malecki, Institute of Nuclear Physics (Poland)

Poster Session

Dariusz Bocian, Institute of Nuclear Physics (Poland) 
Proc. of SPIE Vol. 11054 1105401-10

Downloaded From: https://www.spiedigitallibrary.org/conference-proceedings-of-spie on 26 Apr 2023 Terms of Use: https://www.spiedigitallibrary.org/terms-of-use 


\section{Introduction}

We are pleased to present the proceedings from the Fourth Conference on Superconductivity and Particle Accelerators (SPAS 2018). The conference was held 27-29 November 2018 in Kraków at The Henryk Niewodniczański Institute of Nuclear Physics Polish Academy of Sciences (IFJ PAN). This volume contains 22 articles submitted by the authors. The full presentations from the SPAS 2018 sessions are available publicly at the conference website, presented in the CERN InDiCo standard: https://indico.ifj.edu.pl/event/214/timetable/\#all.detailed. The conference gathered around 80 participants from main institutions active in accelerator technologies in Poland and from a few key European, American, and Asian accelerator research laboratories. A total of 70 oral and poster papers were presented.

The conference was devoted to research in the domain of superconductivity and its applications in science, as well as to the research in the field of particle accelerators, conducted in Polish research institutions as well as by Polish scientists working in the international laboratories. It is a continuation of the previous conferences, held at the IFJ PAN in 2012, 2014, and 2016. The objective of this conference was to identify current and potential areas of the research in superconductivity and particle accelerators, developed and possible to be developed in Poland and to determine the needs in the infrastructure to support this research. The previous SPAS conferences were held as follows: SPAS 2012 in conjunction with the TIARA Poland mid-term meeting 2012 - September 27-28; SPAS 2014 - December 9-10; and SPAS 2016 - December 6-7.

Dariusz Bocian Ryszard S. Romaniuk 
Proc. of SPIE Vol. 11054 1105401-12

Downloaded From: https://www.spiedigitallibrary.org/conference-proceedings-of-spie on 26 Apr 2023 Terms of Use: https://www.spiedigitallibrary.org/terms-of-use 